\title{
Nuevas aportaciones a la historia de la Iglesia parroquial de Gilena, Sevilla (siglos XVI-XIX)
}

\author{
New Contributions to the History of the Parish \\ Church of Gilena, Seville (16th-19th centuries)
}

\author{
Jorge Alberto Jordán Fernández \\ Universidad de Sevilla \\ jorgeajordan@gmail.com \\ ID ORCID 0000-0003-3197-2171
}

\begin{abstract}
Resumen: Ampliación de un estudio anterior (Isidorianum 24 [2015] 47-48) en la que se dan a conocer nuevas aportaciones acerca del devenir histórico de la iglesia parroquial de Gilena (Sevilla) desde sus orígenes, en el siglo XVI, hasta el siglo XIX.
\end{abstract}

Palabras claves: Gilena, iglesia parroquial, patrimonio artístico, siglos XVI-XIX.

\begin{abstract}
This paper is an extension of a previous study (Isidorianum 24 [2015] 47-48) in which new contributions are made about the historical evolution of the Parish Church of Gilena (Seville), from its origins, in the 16th century, to the 19 th century.
\end{abstract}

Keywords: Gilena, parish church, artistic heritage, $16^{\text {th }}-19^{\text {th }}$ centuries.

\section{INTRODUCCIÓN}

El presente trabajo puede considerarse continuación del que anteriormente dedicamos a la historia del templo parroquial de Gilena, advocado de la Purísima Concepción; ${ }^{1}$ la aparición de documentación inédita y, con ella, de nuevos datos, ha hecho que nos planteemos volver sobre el tema para dar a conocer dicha documentación y confrontar la información que aporta con lo escrito anteriormente, al intento de arrojar más luz sobre el asunto.

En la primera parte de este estudio damos a conocer ciertos documentos inéditos que nos aportan nuevos datos acerca de las

1 Cf. Jorge Alberto JoRDÁn FerNÁNDEZ, “La iglesia parroquial de Gilena en el tránsito del siglo XIX al xx (1874-1928)", Isidorianum 24/47-48 (2015) 307-363. 
vicisitudes por las que pasó la iglesia de Gilena desde sus orígenes hasta comienzos del siglo XVIII, antes de la gran transformación que se llevó a cabo en el templo. En la segunda parte, damos igualmente a conocer documentos inéditos que arrojan luz sobre la procedencia de algunas de las imágenes escultóricas que hoy forman parte del patrimonio artístico del templo gilenense y que llegaron al mismo en los últimos decenios del siglo XIX.

\section{EN TORNO A LOS ORÍGENES DE LA IGLESIA}

En nuestro anterior trabajo sobre la iglesia de Gilena establecimos su antigüedad, siguiendo a Madoz, en torno al año 1620, un siglo antes de su erección como parroquia. La aparición de nueva documentación, conservada en un expediente del archivo arzobispal de Sevilla, hace que tengamos que adelantar la fecha de su existencia al menos hasta el año 1580, como nos revela el más antiguo de los documentos que contiene. El expediente en cuestión conserva varios documentos relacionados con la fábrica de la iglesia de Gilena, abarcando un arco temporal que va desde 1580 hasta 1701, los cuales nos aportan interesantes noticias sobre los primeros siglos de historia de aquella iglesia. ${ }^{2}$

El documento más antiguo, del año 1580, contiene unos autos seguidos ante el entonces vicario de Estepa, Miguel Sánchez de Saldaña (1549-1598), último de los vicarios santiaguistas, por Antón Ruiz, "mayordomo de la iglesia del cortijo de Gilena, jurisdicción de esta villa [de Estepa]", quien el 7 de noviembre de aquel año se dirigió por escrito a dicho vicario, máxima autoridad eclesiástica en aquel territorio exento de la jurisdicción episcopal, solicitando su licencia para poder dar a censo diez fanegas de tierra calma que estaban "divididas en tres hazas que son en el término de la villa de Pedrera y en el de esta villa [de Estepa]", las cuales había dejado a la iglesia de Gilena Francisco Sánchez Nieto,"morador que fue en el dicho cortijo [de Gilena]"en su testamento "debajo del cual murió"; estas fincas estaban en aquel momento arrendadas por dos años a un vecino de Pedrera "por cierto precio de maravedís", pero "porque

2 El expediente en Archivo General del Arzobispado de Sevilla (AGAS), Justicia, Hermandades, legajo 09929, al cual van referidas las citas textuales que se incluyen en este apartado, salvo indicación expresa, lo que advertimos para evitar la innecesaria reiteración de notas. 
en estos dichos dos años ha visto mucha quiebra en la cobranza de los reales a causa de las esterilidades y por otros inconvenientes", le convenía entonces" a la dicha iglesia que las dichas tierras se den a censo a la persona que más diere por ellas, andando en pregón conforme a derecho".

En apoyo de su solicitud, el mayordomo de la iglesia de Gilena presentó la declaración de cuatro testigos, a quienes se les tomó juramento con todas las formalidades requeridas por el derecho el mismo día 7 de enero, en presencia del notario eclesiástico, Juan de Arrieta. Estos testigos, vecinos todos ellos de Estepa y algunos moradores "en el cortijo de Gilena", fueron Alonso Jiménez de Carmona, de 40 años; Mateo García Valero, de 26 años; Antonio de Villalobos, de 28 años; y Pedro Romero, de 30 años. Los cuatro testigos declararon en la villa de Estepa y venían a coincidir en sus respectivos testimonios, apenas con algún leve matiz diferenciador, por lo que podemos tomar como modelo la declaración efectuada por el primero de ellos, Alonso Jiménez:

[...] dijo este testigo sabe y tiene noticia de las diez fanegas de tierra que Francisco Sánchez dejó a la iglesia de Gilena, que son las contenidas en el dicho pedimento, las cuales sabe este testigo que si la dicha iglesia de Gilena, y su mayordomo en su nombre, diesen a censo las dichas diez fanegas de tierra sería más útil y provechoso a la dicha iglesia, respecto de que si se diesen al dicho censo estaría segura la renta y censo de ella, lo cual no está dándolas a renta cada año, porque unos años se habría útil la dicha renta y otros con esterilidad. Y porque estos inconvenientes cesarían y no los habría dándolas al dicho censo a la persona que más diese por ellas. $Y$ porque este testigo sabe que algunos de los arrendadores que las han tenido a renta, unos se han ido con la dicha renta y otros no la han pagado ni pagan por entero.

Concluidas que fueron las diligencias de declaración, se acompañaron a la solicitud presentada por el mayordomo de la iglesia de Gilena al vicario de Estepa, quien, el mismo día 7, estando en Estepa, dictó un auto en el que, "habiendo visto lo pedido por el dicho Antón Ruiz, mayordomo, y la información por él dada", ordenaba la remisión del expediente a su superior jerárquico, el "Rvdmo. Señor Prior de esta Provincia para que Su Señoría lo vea e provea justicia", por lo que desconocemos si finalmente se concedió la licencia solicitada. Nada de extraño tiene, por otra parte, la remisión de las actuaciones al prior de la provincia de León de la orden santiaguista, por cuanto 
hasta el año 1587 no sentenció el tribunal de la Rota la definitiva separación de dicha orden de la jurisdicción eclesiástica del territorio estepeño, que recayó a partir de entonces en los marqueses de Estepa. ${ }^{3}$ Lo que sí queda patente por este testimonio documental es la existencia de una iglesia en Gilena al menos desde los años ochenta del siglo XVI.

Los siguientes documentos conservados en el expediente que venimos analizando datan del año 1697; se trata de unos autos seguidos ante el vicario de Estepa, a la sazón, Lorenzo de Andújar, ${ }^{4}$ por el licenciado Andrés Domínguez de Ordaz," cura de la iglesia del lugar de Gilena, de esta jurisdicción", quien el día 4 de septiembre de aquel año presentó un escrito en la notaría eclesiástica solicitando el abono de ciertas cantidades de dinero que había satisfecho de su propio peculio con motivo de las obras que entonces se estaban llevando a cabo en aquella iglesia, tal como se contaba en la petición realizada por el mencionado presbítero:

Que en la obra que se hizo de mi cuenta para acabar de perfeccionar la obra de dicha iglesia he gastado las partidas de maravedís contenidas en este memorial de que hago presentación con el juramento necesario, excepto la primera y última partida de dicho memorial que se hallan pagadas a Alonso Gómez y Cristóbal Jiménez, mayordomos de la fábrica de dicha iglesia, de cuyas cantidades se me debe dar satisfacción por dichos mayordomos de las rentas y frutos más prontos que tuvieren de dicha fábrica.Y para justificación de la certeza de dichas partidas de dinero, que se reciban declaraciones por la persona queV. S. nombrare, con asistencia de dichos mayordomos. Y verificada la certeza de los gastos, que se me dé satisfacción sin dilación ninguna. Y asimismo de 24 reales que por dicha fábrica pagué del Ldo. D. Rodrigo de Vergara, como consta deber del recibo de que hago presentación.

3 Cf. José Ma Fernández Catón, “La documentación de la Orden de Santiago en el Archivo Histórico Diocesano de León y los pleitos entre el prior de San Marcos de León y el marqués de Estepa sobre la jurisdicción eclesiástica de la vicaría de Estepa en la segunda mitad del siglo XVI", en Actas de las IV Jornadas sobre Historia de Estepa. La vicaría eclesiástica de Estepa, Ayuntamiento de Estepa, 2000, $35-45$.

4 Ejerció su cargo como vicario de Estepa entre 1685 y 1708, en virtud de nombramiento recibido de los marqueses de Estepa como señores espirituales de su estado. 
Tanto el memorial como el recibo que se citan en el anterior escrito los reproducimos íntegramente en el apéndice de este trabajo, de cuyo contenido se desprenden pagos directamente relacionados con las obras de la iglesia, tales como los del maestro de albañil, peones, maestro carpintero, ladrillos, clavos y cal "para revocar la obra", y otros que no lo están tanto, tales como los del"vino que se gastó en la obra y en segar el pegujar del año de 1695".

Pues bien, en atención al anterior escrito y a los documentos que lo acompañaban, el vicario Andújar dictó un auto ese mismo día 4 de septiembre por el cual daba comisión al licenciado Juan de Zamora Vera y Aragón, presbítero de Estepa, "para que como juez y notario haga todos los autos y diligencias que se piden, y hechos, traigan los autos para los ver y proveer justicia". En virtud de esta comisión, el presbítero Zamora se desplazó a la puebla de Gilena al día siguiente para tomar declaración jurada a los mayordomos de la iglesia del lugar, a la sazón Alonso Gómez, de 50 años, y Cristóbal Jiménez, de 40 años, ambos moradores del lugar, cuya diligencia fue recogida en los siguientes términos:

[...] y habiéndoles mostrado y leído el memorial que en dicha petición se contiene, y preguntados si el Ldo. D. Andrés Domínguez de Ordaz, cura de dicha puebla, había distribuido y dado las partidas a los sujetos que en él se mencionan, dijeron que es verdad que dicho cura gastó y pago los 669 reales y 3 cuartillos que importan las partidas y los distribuyó y pagó a las personas que se mencionan en dicho memorial y que dicho dinero fue suyo, de dicho cura, que lo dio para la obra de dicha iglesia, como también la partida que contiene la carta de pago del Ldo. D. Rodrigo de Vergara, que se dio de unas diligencias que el susodicho fue a hacer a dicha puebla, que había de pagar dicha fábrica. Cuyas partidas hacen los dichos 669r y 3 cuartillos $[\ldots]$.

De vuelta ya en Estepa, el presbítero Zamora entregó las diligencias practicadas en la notaria eclesiástica de la villa, a cuya vista, el vicario Andújar tomó la siguiente resolución, fechada el 10 de septiembre de aquel año:

[...] mandó se despache mandamiento en forma al mayordomo de la fábrica de Gilena para que pague la cantidad de maravedís contenida en la memoria, de los frutos más prontos que estuviesen en su poder de dicha fábrica, al Ldo. D. Andrés Domínguez de Ordaz, dándose por el susodicho recibo al pie de dicho mandamiento. 
Del análisis de la documentación parece determinarse que las obras costeadas por el cura de Gilena se correspondían con una reforma del templo, incluyendo asimismo labores de mantenimiento, como se desprende del siguiente apunte:"pagué al gitano $5 \mathrm{r}$. de aderezar las hormas de la campana".

Más en consonancia con la reforma del templo de Gilena está la siguiente documentación conservada en el expediente, que data de 1701; se trata de unos autos iniciados el 26 de septiembre de aquel año a instancia del hermano Juan del Espíritu Santo, sacristán nombrado por el vicario Andújar para cuidar del culto divino en la iglesia de Gilena, solicitando la licencia del prelado para llevar a cabo la construcción de un retablo de yeso para la iglesia de su cargo, en base a las siguientes alegaciones:

Que entre los moradores y bienhechores, así de dicho lugar como de todos los demás de este término, para exceso de dicho culto tengo juntos de limosna 100 ducados de vellón que se hallan en mi poder; y para que se logre el fin de los bienhechores y en adelante se alienten a contribuir con sus limosnas, tengo tratado y concertado con Juan Rodríguez Bermudo, maestro mayor de obras de la villa de Osuna, en 1.500 reales vellón el hacer retablo de yeso cortado según el dibujo que tengo demostrado a V. S. que es la mayor necesidad que tiene dicha parroquia por no tenerlo de talla ni de otro género, bajo de las condiciones de poner por mi parte todos los menesteres excepto el corte y marcos de dicho retablo y de cocer y majar el yeso necesario para que se consiga y dé principio la referida obra.

En respuesta a la anterior solicitud, el vicario Andújar dictó ese mismo día un auto cuyo tenor era el siguiente:

Esta parte dé principio a la dicha obra, que desde luego se le aprueba el ajuste que tiene hecho, y gaste los 100 ducados que confiesa tener en su poder, con cuenta y razón y reservase, para en vista de la cuenta por lo que faltase a todo el pago, el despachar libranza contra el mayordomo de la iglesia del lugar de Gilena.Y para el buen éxito de la obra contenida en el pedimento se le notifique a Juan Rodríguez Bermudo, maestro que la tiene ajustada y que ha de correr de su cuenta, se obligue por tiempo a hacer dicha obra por contrato ante escribano público de esta villa; y sobre todo su tenor ya interponía e interpuso su autoridad y decreto judicial para su mayor validación. Y al hermano Juan se le notifique dichos 100 ducados y estos fenecidos y gastados acuda a dar la cuenta para que se le despache dicho libramiento. 
El auto anterior fue notificado el mismo día al hermano Juan del Espíritu Santo y al maestro Juan Rodríguez Bermudo y aquí se terminaría el expediente, de no tener constancia a través de cierto documento notarial de que la obra fue efectivamente contratada entre las partes también ese mismo día; de esta manera, nos consta que el maestro Bermudo se obligó a realizar un retablo de yeso cortado de ocho varas de alto para la capilla mayor de la iglesia de Gilena según cierto dibujo "que tenía el sacristán de la iglesia, Juan del Espíritu Santo, que le había entregado al señor Vicario", comprometiéndose a tenerlo acabado para el día de la Inmaculada de aquel año y percibiendo por ello un total de 1.500 reales de vellón, según las condiciones pactadas entre las partes, de donde deducimos que el sacristán necesitó 400 reales más para poder finiquitar el coste de la obra, que suponemos le fueron satisfechos por el mayordomo de aquella iglesia, tal como se desprendía del auto del vicario. ${ }^{5}$

\section{NOTICIAS SOBRE SU PATRIMONIO ESCULTÓRICO}

Varias son las aportaciones que hacemos acerca del patrimonio escultórico, que se conserva actualmente en la iglesia de la Purísima Concepción de Gilena, las cuales exponemos a continuación.

\subsection{Escultura de la Virgen de los Dolores}

La imagen está colocada en la actualidad en un camarín cuya embocadura está rodeada por un retablo y altar en madera dorada y policromada en varios colores; en nuestro anterior trabajo, siguiendo a autores locales, atribuimos la hechura de esta imagen a sor Ana de San José, religiosa profesa en el monasterio de Santa Clara de la vecina localidad de Estepa, quien la habría realizado en $1772 ;{ }^{6}$ la atribución original la realizaron los citados autores basándose en un papel encontrado en el interior de la imagen al ser sometida a restauración,

5 La noticia es recogida por Jesús $\mathrm{M}^{a}$ ReINA y otros, Gilena y su comarca en el siglo XVIII, Sevilla, Diputación de Sevilla, Sevilla, 2007, 131, según una escritura conservada en el Archivo de Protocolos Notariales de Estepa.

6 Cf. Jordán Fernández, "La iglesia parroquial de Gilena", 328, siguiendo a Jesús $\mathrm{M}^{\mathrm{a}}$ ReINA - José ReINA, Aproximación a la historia de Gilena (siglos XVIII, XIX, XX), Gilena, Ayuntamiento de Gilena, 2001, 45. 
cuyo texto íntegro reprodujeron en otra publicación posterior. ${ }^{7}$ Dicho texto, con forma de corazón y escrito de una misma mano, está encabezado por un saludo inicial, "Ave María", una fecha, "Año de 1772" y la fórmula piadosa "Todas te ofrecemos, Señora, en este [corazón] nuestros corazones"; a continuación vienen los nombres de las religiosas que constituían la comunidad de clarisas estepeñas en aquel año y, separado por una raya discontinua, la siguiente inscripción: "Se hizo esta Señora de los Dolores en este convento de Santa Clara de Jesús, en Estepa, año 1772; siendo pontífice No Ssmo. P. Clemente 13: y rey de España, Sr. D. Carlos 3"; después se traza una nueva línea discontinua y se inserta una nueva inscripción: "A vuestras plantas, rendidamente, esta esclava infiel pidiéndote me perdones, Sor Ana de S. Joseph"; y finalmente, tras otra línea discontinua, se escribe: "Viva Jesús, Viva María, vivan, vivan". De la lectura de cuanto acabamos de transcribir se infiere que la imagen de la Virgen de los Dolores, en cuyo interior se encontraba el papel, se hizo en el convento de Santa Clara de Estepa en 1772, pero no resulta igual de claro, a nuestro entender, que la autora de dicha imagen fuese sor Ana de San José, es más, nosotros pensamos que no lo fue, como vamos a ver a continuación y que lo único que parece evidente es que dicha religiosa fue quien escribió el papel y poco más. Para empezar diremos que la relación de los nombres de las religiosas que formaban la comunidad en aquel momento no está escrita al acaso sino siguiendo un estricto protocolo; así, en primer lugar figura la abadesa del monasterio, sor $\mathrm{M}^{\mathrm{a}}$ Isidora de Santa Gertrudis; a continuación, la que suponemos madre vicaria, sor Juana $\mathrm{M}^{a}$ del Carmen; ${ }^{8}$ después, las madres discretas o consejeras de la comunidad; terminada la relación de discretas, la lista continúa por las religiosas profesas siguiendo estrictamente el orden de antigüedad en la profesión, escribiéndose el nombre de la monja seguido de su apellido religioso, dándose una única variación

\section{Cf. ReInA - ReInA, Aproximación a la historia, 134 y 148-149.}

8 Esta religiosa, en el siglo llamada Juana $\mathrm{M}^{\mathrm{a}}$, hija de Andrés de Luna y Matilde Gutiérrez, que profesó sin dote en el convento estepeño en 1717 a los 15 años, muy posiblemente fuese oriunda de Gilena. De hecho, en el vecindario de la localidad de 1761 aparece una "Matilde de Luna, viuda, pobre, tiene dos hijos, uno mayor, y una hija", que posiblemente sea familiar de la religiosa; cf. Antonio Rivero - José Luis Prieto (coords.), Clausura. Monasterio de Santa Clara de Jesús, Estepa, Ayuntamiento de Estepa, 1999, 93; y ReInA y otros, Gilena y su comarca, 126. 
en la manera de escribir dichos nombres precisamente al llegar al de sor Ana, que se escribe "sor Ana M ${ }^{a}$ de mi Señor San Joseph", aunque la fórmula era usual en los escritos de la época el hecho de que aquí sea la única vez que se use nos lleva a concluir que la autora del texto fue esta religiosa. ${ }^{9}$ Por otro lado, si sor Ana $\mathrm{M}^{\mathrm{a}}$, que en 1772 contaba con 26 años, ${ }^{10}$ hubiese destacado en el arte de la escultura en su monasterio resulta un tanto desconcertante que en las crónicas del cenobio no se mencione este hecho o que no contase este con más obras escultóricas salidas de las manos de la religiosa, circunstancias ambas que no hubiesen pasado desapercibidas para los historiadores del monasterio estepeño; la procedencia de las esculturas de este cenobio ha sido estudiada por Herrera García, quien, en relación tal vez con el tema que venimos tratando, nos da noticia de que una Dolorosa de vestir que estaba colocada"en la ermita [del claustro] con su altar" fue traída al convento de Estepa por sor $\mathrm{M}^{\mathrm{a}}$ Aniceta de la Concepción, una de las religiosas mencionadas en la lista, que había profesado en 1767, a los 26 años de edad, por tanto, después que sor Ana $\mathrm{M}^{\mathrm{a}}$; por cierto, dicha imagen está hoy sin localizar pues Herrera la identifica con una Dolorosa de origen bien distinto, como advertimos en otro lugar, por ello no debiera descartarse que fuese la que está hoy en la parroquia de Gilena. ${ }^{11}$ En conclusión, creemos que la aparición del papel en el interior de la imagen, lejos de aclarar su autoría, aporta elementos de confusión pues si admitimos que no fue realizada por la monja se abre todo un campo de interrogantes de difícil respuesta.

9 Los datos sobre la profesión de cada religiosa pueden verse en RIVERO - PRIETO, Clausura, 93-96.

10 Sor Ana $\mathrm{M}^{\mathrm{a}}$, en el siglo Ana $\mathrm{M}^{\mathrm{a}}$ Baena Alés, nació en Estepa hacia 1746, profesó en el convento de su villa natal el 18 de mayo de 1766 y sus padres, Pedro Baena y María Afán [sic. ¿Alés?], no aportaron dote alguna en la profesión de su hija por ocupar una de las plazas sufragadas por el marqués de Estepa; cf. RIVERO - PRIETO, Clausura, 95.

11 Cf. Francisco Javier Herrera García, "Retablos y esculturas que hay en este monasterio de Santa Clara de Jesús" en Rivero - Prieto, Clausura, 214, n. 51; Jorge Alberto Jordán FERnÁndez, "La hermandad del Santo Entierro de Estepa: notas para su historia (ss. XVI-XIX)", en Actas I Simposio "La devoción a la Soledad y Santo Entierro en el antiguo reino de Sevilla", Castilleja de la Cuesta, Hermandad de la Soledad, 2016, 55. Por cierto, Herrera añade en la nota citada:"sabemos que esta monja [sor Aniceta] se hallaba en el convento en el año de 1772". 


\subsection{Esculturas de la capilla de la Santísima Trinidad}

Nos estamos refiriendo a tres esculturas que se citan por primera vez en el inventario de la iglesia de Gilena del año 1928 como situadas en la capilla de la Santísima Trinidad, fundación de Francisco García Díaz en 1878. Las tres esculturas son: Santa Ana con la Virgen Niña de la mano, San Francisco de Paula y San Joaquín con la Virgen Niña en sus brazos. ${ }^{12}$ Hasta ahora, la procedencia de estas tres imágenes y el momento de su llegada a la parroquia no se conocían a ciencia cierta. Sobre el grupo escultórico de Santa Ana y la Virgen, los autores del Catálogo, a mediados del siglo pasado, se hicieron eco de una tradición oral existente en el pueblo según la cual procedía del desaparecido convento casa grande de San Francisco de Sevilla. ${ }^{13}$ Más recientemente, otros autores afirmaban que las tres esculturas a que nos estamos refiriendo fueron traídas a la iglesia parroquial de Gilena en una fecha indeterminada por el presbítero Juan José Guerra, ${ }^{14}$ pero el reciente hallazgo de ciertos documentos nos aclara bastante cuál sería la verdadera procedencia de las tres piezas escultóricas. Así pues, sabemos por un expediente conservado en el archivo del arzobispado sevillano que el 10 de noviembre de 1894 el entonces cura propio de la parroquia de Gilena, Antonio Gutiérrez de Quevedo, presentó una instancia en el arzobispado de Sevilla en la que decía:

[...] en la iglesia de los PP. del Oratorio [Filipenses] de esa ciudad y en uno de sus almacenes se encuentran dos esculturas una de [interlineado: San Joaquín y] Señora Santa Ana y otra de San Francisco de Paula, las cuales no pueden ser expuestas al culto en aquella iglesia por haber sido reemplazadas por otras propias de dicha Congregación, y estando conforme en cederlas el R. P. Prepósito de la misma,

Suplica a V.E.R. se digne conceder su superior licencia para que sean trasladadas a esta parroquia donde recibirán los homenajes del culto en lugar convenientemente preparado en la capilla de la Santísima Trinidad $[\ldots] .^{15}$

En respuesta a la anterior solicitud, el arzobispo de Sevilla, cardenal Sanz y Forés (1889-1895), decretó el 24 de noviembre que

\footnotetext{
12 Cf. JORDÁn FERnÁNDEZ, “La iglesia parroquial”, 339-340.

13 Cf. José Hernández Díaz, José y otros, Catálogo arqueológico y artístico de la provincia de Sevilla. Sevilla, Diputación Provincial, 1955, vol. IV, 195, n. 9.

14 Cf. ReIna y otros, Gilena y su comarca, 135-136.

15 El expediente en AGAS, Gobierno, Asuntos Despachados, legajo 314 (04818).
} 
informase sobre la misma el P. Prepósito de los filipenses, a la sazón Manuel de la Oliva, "lo que se le ofrezca y parezca"; el informe del superior de los filipenses lleva fecha del 28 de noviembre y en él afirmaba su autor lo siguiente:

Existen efectivamente en nuestro poder las referidas esculturas de Santa Ana y San Francisco de Paula, sin que hoy tengan culto; de ambas puede, por consiguiente, disponer nuestro Emmo. Prelado, advirtiendo únicamente se conceda el uso y no la propiedad, por si alguna vez hay quien reclame, pues ambas pertenecen a la iglesia.

A la vista del anterior informe, el prelado decretó, en 7 de diciembre, la entrega de las esculturas "como se pide y en calidad de depósito"; aunque el prepósito filipense solo menciona dos esculturas en su informe hay que entender que se incluye también la de San Joaquín con la Virgen en brazos, pues las tres esculturas se mencionan en los inventarios que conocemos de la iglesia de San Alberto de Sevilla, adonde se habían trasladado los filipenses en 1878, y las tres se encuentran hoy en la iglesia parroquial de Gilena.

De estas imágenes, el grupo escultórico de Santa Ana con la Virgen Niña es el que ofrece mayores dificultades para su correcta identificación, debido a lo contradictorio de los datos que se conocen acerca de la misma; así, por un inventario de la iglesia de San Alberto, fechado el 24 de septiembre de $1835,{ }^{16}$ sabemos que al tiempo de la exclaustración de los frailes carmelitas existían en aquel templo dos imágenes de Santa Ana: una primera es citada como Santa Ana con el Niño [sic, ¿la Virgen Niña?] en los brazos y se encontraba colocada en el retablo mayor, en uno de los lados de la embocadura del camarín, formando pareja con una escultura de San José, ${ }^{17}$ la otra imagen de Santa Ana, "de algo más de vara y media", con la Virgen María,"de menos de vara", estaba colocada en el retablo de una de las capillas laterales de la nave, llamada del Sagrario o de Santa Ana. Por su parte el inventario de la iglesia que se realizó el primero de junio de

16 El inventario en AGAS, Gobierno, Órdenes Religiosas Masculinas (ORM), legajo 21, expediente 1.

17 Sobre la iconografía de santa Ana, cf. Louis RÉAU, Iconografía del arte cristiano. Iconografía de los Santos. De la A a la F, t. II, vol. 3, Barcelona, Ediciones del Serbal, 2000, 75-80. No es infrecuente la representación de santa Ana con laVirgen Niña en brazos, sí lo es, en cambio, con el niño Jesús. 
1878, al tiempo de hacerse cargo de ella los oratorianos, ${ }^{18}$ aunque más escueto, vuelve a mencionar también dos imágenes escultóricas de Santa Ana: una de ellas se encontraba en el retablo mayor,"en la parte baja" del mismo, formando pareja con la de San José; y la otra se cita entre las "imágenes pertenecientes a la iglesia que no tienen altar propio", describiéndose al propio tiempo como una imagen de "tamaño natural"; desafortunadamente, en ambos casos no se especifica en el inventario si las imágenes de la santa iban acompañadas de la Virgen Niña.

Las descripciones de este templo carmelitano que en su día realizaron Félix González de León y José Gestoso nos aportan más noticias acerca de las imágenes de Santa Ana que allí existieron; así González de León, que escribió antes de la llegada a San Alberto de los filipenses, nos dice que en la primera capilla del lado del evangelio de la nave, inmediata al púlpito y destinada a comulgatorio, había "una Santa Ana, bellísima escultura de Alonso Cano". ${ }^{19}$ Por su parte Gestoso, que escribió después del establecimiento de los filipenses, relataba, al describir el altar mayor de la iglesia, que en su nicho principal se veneraba" una efigie de Nuestra Señora Dolorosa, muy devota, pero de escaso interés artístico" y a los lados de ese nicho se veían "dos esculturas: en el de la epístola, Santa Ana y la Virgen, bellísimo grupo que algunos atribuyen a Alonso Cano, pero que nos parece posterior a aquel insigne maestro; y en el del evangelio, San José, obra apreciable, pero no de tan buena mano como la compañera. Ambas están delicadamente estofadas"; en nota a pie, Gestoso daba la noticia de que estas dos esculturas habían pasado a la iglesia del Buen Suceso..$^{20}$ De la descripción de Gestoso algunos autores han interpretado que al hablar de la Santa Ana del retablo mayor se estaba refiriendo a la misma imagen escultórica que González de León vio en una de las capillas laterales del templo, la cual habría sido cambiada

18 Este otro inventario igualmente en AGAS, Gobierno, ORM, legajo 21, expediente 1.

19 Félix GonZÁlez de LeÓN, Noticia artística, histórica y curiosa de todos los edificios públicos, sagrados y profanos, de esta ... ciudad de Sevilla..., t. I, Sevilla, Imprenta de D. José Hidalgo y Compañía, 1844, 166.

20 Cf. José Gestoso y Pérez, Sevilla monumental y artística... t. III, Sevilla, Oficina Tipográfica de El Conservador, 1892, 495 y 497, n. 1. Hay que advertir que este tomo es bastante posterior a la fecha de impresión que aparece en su portada, pues consta en su colofón que terminó de imprimirse en julio de 1897 y que en su texto se recogen noticias que llegan al menos hasta el año 1896 (p. 380). 
de sitio, cuestión que para nosotros no está tan clara después de cuanto llevamos dicho, máxime sin tener la certeza de que el nicho colateral del retablo mayor, dado su tamaño, pudiese albergar las dos imágenes de Santa Ana y la Virgen Niña. ${ }^{21}$

Los historiadores del arte identifican el grupo de Santa Ana con la Virgen Niña que hubo en San Alberto con el que actualmente se encuentra en la iglesia sevillana del Buen Suceso, obra atribuida a Martínez Montañés. ${ }^{22}$ Si esto fue así, deberemos entonces realizar una digresión en nuestro discurso para determinar con la mayor exactitud posible la fecha en que dicho grupo escultórico de Santa Ana pasó a la iglesia de los carmelitas del Buen Suceso, ya que la propuesta por algunos historiadores (1893) nos parece poco probable. ${ }^{23}$

Para empezar, sabemos que desde mayo de 1876 el arzobispado de Sevilla había concedido autorización a los filipenses para realizar en la iglesia de San Alberto los ejercicios piadosos propios de la congregación. Posteriormente, el arzobispo Lluch y Garriga (1877-1882), religioso carmelita, por un decreto suyo fechado el 24 de noviembre de 1877, nombró capellán de san Alberto al entonces prepósito de los filipenses, P. García Tejero, por el tiempo de su voluntad:

[...] para que cuide de su aseo y conservación, y a fin de que tanto él como su Congregación puedan celebrar en ella los ejercicios de su Instituto [...]; debiendo empero conservar los altares, retablos y efigies en los propios

21 Cf. Lina Malo Lara, La iglesia de San Alberto de Sevilla en el siglo XVII, Sevilla, Diputación Provincial, 2015, 114. El cambio, desde luego, podría entrar dentro de lo posible por cuanto, según el inventario de 1878, en la capilla donde originalmente estuvo la Santa Ana que cita González de León, en aquel momento había varias imágenes pertenecientes a la congregación del Oratorio, siendo originario de la iglesia tan solo el retablo y una imagen de San Juan Bautista; si esto fue así, es decir, que ambos autores se referían a la misma imagen, se debe admitir entonces que el grupo de Santa Ana con la Virgen sustituyó a la imagen que originalmente estaba en el retablo mayor.

22 Cf. Matilde Fernández Rojas, Patrimonio artístico de los conventos masculinos desamortizados en Sevilla durante el siglo XIx: benedictinos, dominicos, agustinos, carmelitas y basilios, Sevilla, Diputación Provincial, 2008, 446; MALO LARA, La iglesia de San Alberto, 113-117. La imagen de la Virgen Niña fue destruida en 1931 y sustituida después por una copia moderna.

23 Así, p. ej., Malo Lara, La iglesia de San Alberto, 114. 
sitios que siempre han ocupado y venido ocupando hasta el presente, sin hacer variación alguna en ellos por ningún concepto. ${ }^{24}$

García Tejero firmó después, el primero de junio de 1878, un inventario de recepción de cuanto se contenía en la iglesia de San Alberto, documento que ya hemos citado más arriba, por el cual constaba que los filipenses habían realizado algunas de las "variaciones" expresamente prohibidas por el decreto del prelado sevillano. Transcurrido algún tiempo, siendo prepósito del Oratorio el P. Manuel de la Oliva, el arzobispo Sanz y Forés decretó el 16 de noviembre de 1893, en virtud de cierto rescripto recibido de la Santa Sede, la concesión en propiedad de la iglesia de San Alberto a los filipenses:

[...] atendiendo al consentimiento de la Orden de los Carmelitas... la declaramos propia de la expresada Congregación [del Oratorio] de Sevilla, para que la posea perpetuamente y la use como propia en todos sus ministerios y funciones: mandando que en breve plazo se haga entrega por el P. Prepósito al R. P. Provincial de los Carmelitas Calzados de todas las imágenes, alhajas y ornamentos que pertenecieron a la misma iglesia y son propiedad de la Orden... ${ }^{25}$

Dos días después, el 18 de noviembre, fue notificado el anterior decreto al prepósito filipense y en fecha posterior, que no consta, "se dio conocimiento al provincial de los carmelitas calzados de la Bética para que usase de su derecho respecto de los objetos sagrados que deben serle entregados por los filipenses" ${ }^{26}$ En relación con este asunto, según consta en una carta que con fecha 27 de diciembre de 1893 dirigió el provincial de los carmelitas, P. Anastasio Borrás, al general de su orden, P. Luis M ${ }^{\text {a }}$ Galli (1889-1900), estos religiosos habían "hecho instancia" al arzobispo de Sevilla para que "no se dé curso al rescripto apostólico por el que se concede a los Filipenses nuestra iglesia de S. Alberto de Sevilla por ser falsos los motivos alegados por ellos", iniciándose a partir de entonces "un enojoso pleito

24 Manuel Martín Riego - José Roda Peña, El Oratorio de San Felipe Neri de Sevilla. Historia y patrimonio artístico, Córdoba, Publicaciones Obra Social y Cultural Cajasur, 2004, 247-248, a quienes seguimos en este asunto.

25 Martín Riego - Roda Peña, El Oratorio de San Felipe Neri, 253-254.

26 Ibíd., 254. 
entre los carmelitas y filipenses que va a durar casi diez años". ${ }^{27}$ Pero lo cierto es que no ha trascendido el contenido de las "instancias" que debieron presentar los carmelitas ante las autoridades eclesiásticas y que, sea de ello lo que fuere, sobre el asunto de la pretendida devolución del templo "nada al final se resolvió". ${ }^{28}$ Fue por ello por lo que los carmelitas, ante la imposibilidad de recuperar San Alberto, se determinaron a buscar otra sede para su fundación sevillana, siéndoles ofrecida por el arzobispado para tal fin la iglesia del Buen Suceso "con algunas habitaciones donde se podrá establecer un Hospicio o Residencia", tal como comunicaba por carta desde Jerez el P. Borrás al general Galli, con fecha 15 de abril de 1896, solicitando su licencia para aceptar el ofrecimiento que les hacían. Obtenida dicha autorización, el P. Borrás se apresuró a solicitar oficialmente la concesión de la mencionada iglesia para su orden al arzobispo Spínola y Maestre (1895-1906), por oficio datado en Jerez de la Frontera el 19 de abril de 1896. Cuatro días más tarde, desde el arzobispado hispalense se accedió mediante el pertinente decreto a la cesión solicitada, por el tiempo de la voluntad del prelado, delegando en el párroco de San Pedro de la capital hispalense para que efectuase la entrega del templo y sus dependencias por inventario, la cual se llevó a efecto el 5 de mayo de aquel año, interviniendo por parte de los carmelitas el definidor P. Eliseo Durán, quien tomó posesión de la misma en nombre de su orden; la iglesia fue reabierta al culto el 15 de julio de $1896 .^{29}$ Ninguna de las fuentes que hemos consultado hace referencia al momento exacto en que los filipenses entregaron a los carmelitas aquellos bienes de San Alberto a que tenían derecho, y que, según

27 Las citas en P. Ismael Martínez CARretero, Los carmelitas en Sevilla. 650 años de presencia (1358-2008), Sevilla, Ediciones de la Provincia Bética, 2009, 641. El rescripto pontificio, fechado en Roma el 30 de agosto de 1893, insistía en que "los Oratorianos han de hacer entrega a los Padres Carmelitas, que en dicha Archidiócesis tienen convento [en Jerez], de todas las imágenes y enseres que sean propios de los Carmelitas y que en dicha iglesia de San Alberto se conservan" (p. 640). Más que de un pleito en sentido jurídico, seguido ante la instancia competente, parece tratarse de un intercambio epistolar entre ambas familias religiosas, del que solo ha trascendido el contenido de un par de misivas del año 1897; cf. Martín Riego - Roda PeÑa, El Oratorio de San Felipe Neri, 254-255; Martínez Carretero, Los carmelitas en Sevilla, 641-642.

28 Martínez Carretero, Los carmelitas en Sevilla, 642.

29 Todas estas noticias y citas en Martínez Carretero, Los carmelitas en Sevilla, 645-651. 
se indicaba en el rescripto pontificio y en el decreto arzobispal, debía efectuarse "en breve plazo"; tan solo hemos hallado esta mención, casi de pasada:

Por la prensa local se tiene constancia de la gran acumulación de fieles que se apiñó en la placita del Buen Suceso en aquel miércoles día 15 de julio [de 1896], vísperas del Carmen, y especialmente el día 16 para venerar la bellísima imagen de Duque Cornejo que hasta entonces se había venerado en el templo conventual de San Alberto. ${ }^{30}$

De donde cabe plantearse como más posible el hecho de que los bienes de origen carmelitano que había en San Alberto fueran devueltos por los filipenses a sus propietarios en una fecha cercana a su instalación en el Buen Suceso, cuyos primeros pasos se dieron, como hemos visto, en la primavera de 1896.

Volviendo, pues, a nuestro discurso, si la primavera de 1896 fue la fecha más probable de devolución a los carmelitas de sus antiguas propiedades procedentes de la iglesia de San Alberto, las cuales, por cierto, no figuran en inventario alguno, resultaría entonces que dicha devolución tuvo lugar varios años después de que el prepósito filipense, como hemos visto más arriba, accediese a que una de las imágenes de Santa Ana con la Virgen que todavía estaban en el templo fuese entregada a la iglesia parroquial de Gilena, de donde queda claro por qué el prepósito filipense advirtió en su informe que "únicamente se conceda el uso y no la propiedad, por si alguna vez hay quien reclame, pues ambas [imágenes] pertenecen a la iglesia".

Pero, entonces, ¿qué imagen fue cedida finalmente a la iglesia de Gilena? En nuestra opinión, si tenemos por cierto que el grupo escultórico de Santa Ana con la Virgen atribuido a Martínez Montañés que hoy se venera en la iglesia carmelitana del Buen Suceso procede de San Alberto, cabría admitir la posibilidad de que la imagen de Santa Ana que se entregó a la parroquia de Gilena fue la que el inventario de San Alberto de 1878 cita como una de las que carecían de altar propio en la iglesia. De confirmarse esta hipótesis, podríamos

30 Martínez Carretero, Los carmelitas en Sevilla, 650. Según este mismo autor, los carmelitas pudieron recuperar "riquísimos ornamentos y las imágenes de Sta. Ana con la Virgen Niña, obra cumbre de Martínez Montañés, y las esculturas bellísimas de Sta. Teresa y de S. Alberto, salidas ambas de la gubia de Alonso Cano, aparte de la Virgen del Carmen ya mencionada"; citado por MARTín RIEGO - RODA PeÑa, El Oratorio de San Felipe Neri, 254. 
identificar entonces la escultura de Santa Ana con la Virgen Niña que hoy se venera en la iglesia parroquial de Gilena con el grupo escultórico que antes de abril de 1631 había labrado el escultor Francisco de Ocampo (1579-1639) para la iglesia carmelitana de San Alberto, el cual se tenía por perdido. ${ }^{31}$ Sobre la Santa Ana de Gilena dijeron los autores del Catálogo que era obra"de hacia 1630, de escuela sevillana, que cabría relacionar con el círculo de Cano", añadiendo en nota que "en la iglesia de Trinitarios de La Rambla y en la parroquia de Palma del Río existen otras imágenes muy análogas en tema, fecha y caracteres artísticos" ${ }^{32}$ No obstante, y por si todo lo que llevamos dicho no fuera suficiente, repárese en cómo la historiadora del arte sevillano Malo Lara describe la escultura de un santo carmelita existente todavía hoy en la iglesia de San Alberto para adjudicarla al quehacer de Ocampo: "Estilísticamente es una obra que remite a Ocampo, especialmente su rostro —ojos grandes y expresivos, de párpados ligeramente caídos, pómulos marcados, nariz recta y boca de labio inferior grueso- - ", 33 y obsérvese cómo dichos caracteres estilísticos se reproducen puntualmente en la Santa Ana de Gilena (ILUSTRACión 1).

En cuanto a la imagen escultórica de San Francisco de Paula, tenemos que decir que es citada en el inventario de San Alberto de 1835 como situada en el retablo del lado de la epístola del crucero de dicha iglesia; este retablo tenía un nicho central con la imagen escultórica de San Alberto,"de poco más de una vara", y a los lados, las esculturas de San Francisco de Paula y San Nicolás de Bari; estas tres imágenes continuaban en su ubicación original todavía en 1878, según el inventario de la iglesia que se hizo entonces, citado más arriba. La de

31 Cf. Fernández Rojas, Patrimonio artístico, 447; Malo Lara, La iglesia de San Alberto, 55-56. La existencia de la escultura se conoce por noticia indirecta de un documento notarial de 1631; cf. Antonio Martín Macías, Francisco de Ocampo, maestro escultor (1579-1639), Sevilla, Gráficas del Sur, 1983, 168.

32 Hernández Díaz y otros, Catálogo arqueológico, t. IV, 192 y 195. Acerca del grupo escultórico de La Rambla, hoy en su iglesia parroquial, decía Hernández Díaz en 1953 que "es patente el recuerdo de la imagen de Montañés de idéntica advocación y análoga composición, venerada en la iglesia sevillana del Buen Suceso, pero posee más intenso barroquismo" y que "en el estado actual de los conocimientos tendremos que situar esta imagen en el círculo de la primera etapa de Cano, todavía con notorio sentido montañesino"; cf. José Hernández Díaz, "Aportaciones al estudio de la imaginería barroca andaluza", Archivo Hispalense, $\mathrm{n}^{\circ} 60,1953,13$.

33 Malo Lara, La iglesia de San Alberto, 152. 
San Francisco de Paula seguramente sea la misma que hoy se encuentra en la iglesia de Gilena, considerada por los autores del Catálogo como una obra del siglo XVIII, tamaño natural y"de mediano interés" (ILUSTRACIÓN 2). ${ }^{34}$

Por su parte, la escultura de San Joaquín con la Niña en sus brazos es citada en el inventario de la iglesia de San Alberto de 1835 situada en la capilla de su mismo nombre del lado del evangelio: "la imagen del Santo, de dos varas de alto, sobre una mesa de altar", junto a una urna que contenía una imagen de la Dolorosa. Ambas imágenes son citadas igualmente en el inventario de la iglesia de 1878 entre las que "no tienen altar propio": de la de San Joaquín se dice en ese inventario que es de "tamaño natural" y de la Dolorosa que es de "medio cuerpo". Esta de San Joaquín debe ser la misma escultura que hoy se venera en la capilla de la Santísima Trinidad de la parroquia de Gilena, que los autores del Catálogo consideraron igualmente como una obra del siglo XVIII"de mediano interés" (ILUSTRACIÓN 3). ${ }^{35}$

\subsection{Escultura de Jesús Nazareno}

Los parcos inventarios de la iglesia de Gilena de comienzos del siglo XVIII que conocemos ya citaban una imagen de Jesús Nazareno colocada en uno de los altares del templo; ${ }^{36}$ autores contemporáneos consideran que la imagen del Nazareno que hoy se venera en un camarín que abre a la nave de la epístola de dicha iglesia es la misma que se citaba en aquellos primeros inventarios, la cual habría sido realizada en el siglo XVII, donada por los marqueses de Estepa, y restaurada en 1873 por Gumersindo Jiménez Astorga (ILUSTRACIÓN 4). ${ }^{37}$ Esos mismos autores se hacen eco también de que tradicionalmente se venía vinculando dicha imagen a la escuela sevillana del siglo XVIII, y posiblemente no le falte razón esta vez a la tradición si atendemos a ciertos documentos localizados en el archivo del arzobispado sevillano. Según consta en un expediente allí conservado, mediante una solicitud firmada en Sevilla por Rafael Filpo, el 14 de julio de 1900, en nombre del presbítero Juan Guerra Rodríguez, "natural de Gilena y vecino de Sevilla", se hacía presente al arzobispo Spínola y Maestre lo siguiente:

\footnotetext{
Hernández Díaz y otros, Catálogo arqueológico, t. IV, 193.

Hernández Díaz y otros, Catálogo arqueológico, t. IV, 193.

Cf. JordÁn FERnÁndeZ, “La iglesia parroquial de Gilena”, 325-326.

Cf. ReInA- ReInA, "Aproximación a la historia”, 48.
} 
Que hace mucho tiempo [el presbítero Guerra] tiene el proyecto de arreglar a sus expensas una capilla con ventana a la calle en la forma que la tiene la parroquia de San Juan Bautista y San Esteban en esta ciudad, en la citada villa de Gilena; y careciendo de una imagen de devoción de N. S. Jesucristo de tamaño natural, al objeto de promover y conservar la piedad en la repetida villa, y no pudiendo hacer mayores sacrificios y gastos, teniendo noticias que en la parroquia de San Gil de esta ciudad existe una de Jesús Nazareno con el título de Las Lágrimas que en la antigüedad estuvo puesta a veneración de los fieles pero que hoy se halla sin culto y almacenada o colocada en la tribuna del órgano; creyendo que la dicha imagen es la más a propósito al objeto indicado, en su virtud, se permite

Suplicar a V.E.R. [...] se sirva conceder la expresada imagen en calidad de depósito a la iglesia parroquial de Gilena para darle el culto debido [...]

Como primera respuesta a la anterior solicitud, dada el 16 de julio, el arzobispo decretó que el párroco de San Gil de Sevilla informase oportunamente sobre la pretensión recibida; el informe del citado párroco, Rafael Delgado, fechado el 21 de julio e insertado a continuación de la solicitud, decía que

[...] Efectivamente existe en esta parroquia de mi cargo una imagen de Jesús Nazareno con el título de Las Lágrimas; y no hallándose expuesta en la actualidad a la veneración de los fieles ni siendo posible por lo pronto llevarse a cabo la restauración que aquella necesita, es del parecer del que suscribe que puede ser concedida en depósito al Sr. D. Juan Guerra y Rodríguez, presbítero, para los fines que se expresa en la precedente solicitud.

A la vista del anterior informe favorable al traslado, el arzobispo dio su asentimiento a lo solicitado por el presbítero Guerra en un decreto fechado el 31 de julio y 1 de agosto, "como se pide y propone". ${ }^{38}$ Nada hemos podido averiguar sobre la imagen del Nazareno de las Lágrimas que se encontraba en la iglesia sevillana de San Gil y tampoco podemos asegurar que finalmente el traslado se llevase a efecto, pero de confirmarse es seguro que entonces tendría más peso la tradición acerca del origen sevillano de la imagen de Jesús Nazareno que hoy recibe culto en la iglesia de Gilena.

\footnotetext{
38 El expediente, al que corresponden todas las citas literales anteriores, en AGAS, Gobierno, Asuntos Despachados, legajo 314 (04818).
} 


\section{APÉNDICE DOCUMENTAL}

1. Memorial del presbítero Andrés Domínguez de Ordaz, cura de la iglesia de Gilena, sobre lo aportado por él a las obras del templo. Gilena, hacia 1695. (AGAS, Justicia, Hermandades, legajo 09929):

Memoria del dinero que voy gastando para acabar la obra de la iglesia: Primeramente le di a Alonso Gómez, 70 r. para un millar de ladrillos. Más pagué a Alonso Gordillo, 26 r. de yeso.

Más pagué a Juan Pérez, maestro de albañil, $100 \mathrm{r}$.

Más pagué a Bartolomé Delgado, maestro de carpintero, 51 r.

Más pagué a Bartolomé Delgado, 99 r. y medio.

Más pagué a Juan Pérez, $218 \mathrm{r}$.

Más le di a Alonso Gómez, 20 r. para clavos de tijeras.

Más le pagué al gitano $22 \mathrm{r}$. de clavos de alfarjía.

Más pagué al gitano $5 \mathrm{r}$. de aderezar las hormas de la campana.

Más di a Bartolomé Delgado un real que hubo de yerro en la cuenta.

Más pagué a Juan Pérez, 90 r.

Más pagué a Agustín González, el de la taberna, 9 r. de tres peones.

Más pagué a Pedro de Alés, 4 r. y cuartillo de cal para revocar la obra.

Más 50 r. de vino que se gastó en la obra y en segar el pegujar del año de 1695.

2. Recibo aportado por el presbítero Andrés Domínguez de Ordaz, cura de la iglesia de Gilena, de un pago efectuado por él. Gilena, 16 de febrero de 1695. (AGAS, Justicia, Hermandades, legajo 09929):

Recibí del Sr. Cura, D. Andrés Domínguez, 24 reales de la fábrica de la iglesia de Gilena, los 12 de un viaje que di a dicho pueblo y los otros 12 por otra diligencia y viaje que volví, ambos con licencia del Sr.Vicario y con despacho de Su Señoría.Y por ser verdad, lo firmé en Gilena en 16 días de febrero de 1695 años.

Son 24 reales. $=$ D. Rodrigo de Vergara . 


\section{APÉNDICE GRÁFICO}

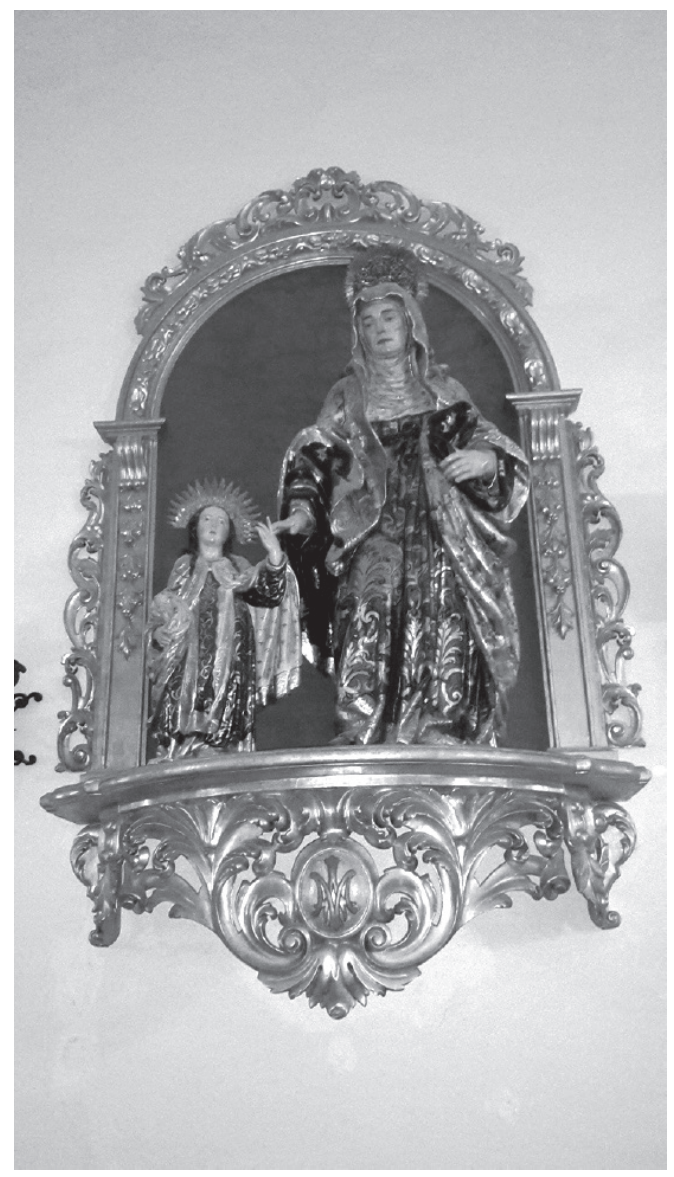

ILUSTRACIÓN 1

Santa Ana con la Virgen Niña. Siglo XVII ¿Francisco de Ocampo? Iglesia parroquial de Gilena (cortesía de Antonio Manuel Rodríguez). 


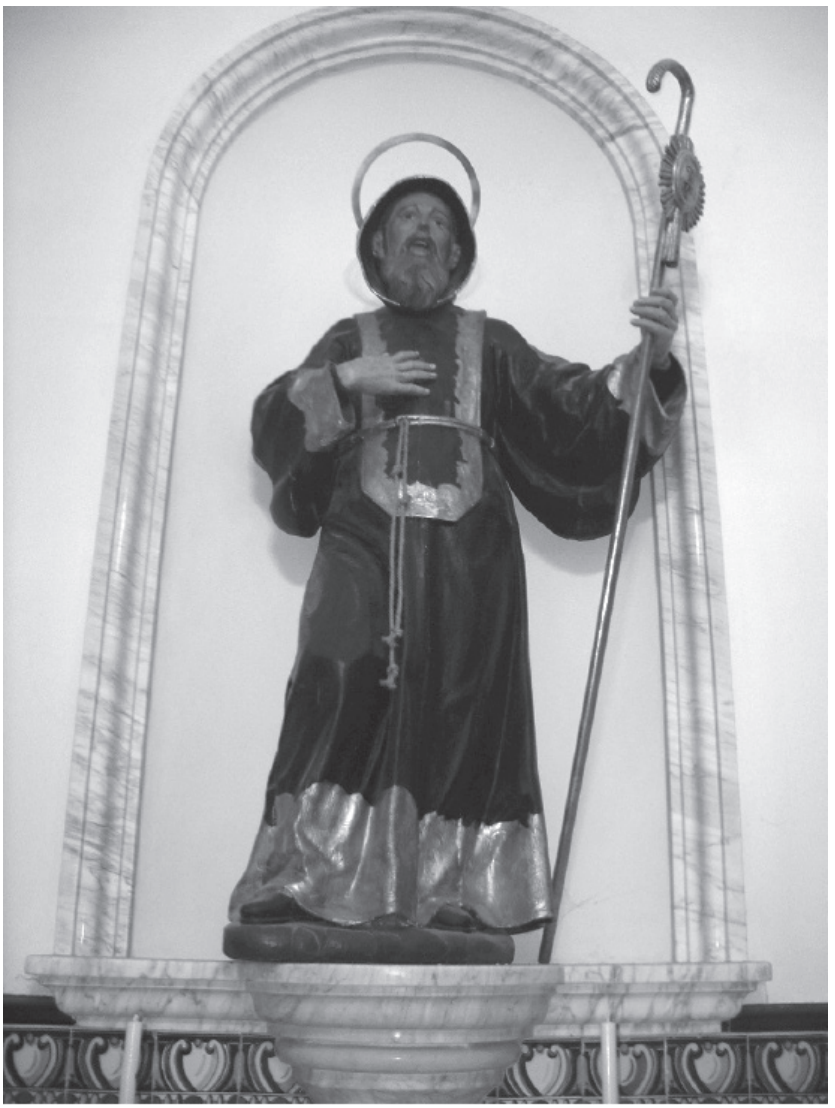

\section{ILUSTRACIÓN 2}

San Francisco de Paula. Siglo XVIII. Anónimo.

Iglesia parroquial de Gilena (cortesía de Antonio Manuel Rodríguez). 


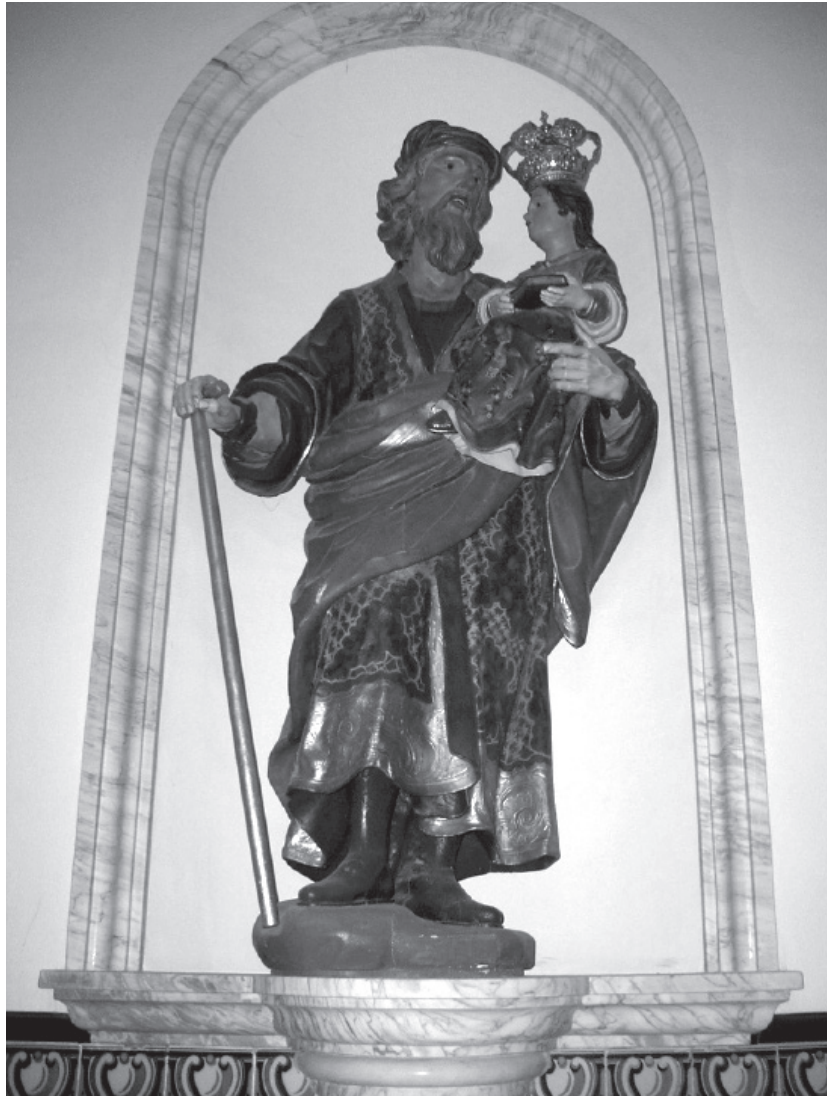

ILUSTRACIÓN 3

San Joaquín con la Virgen Niña en los brazos. Anónimo. Siglo XVIII. Iglesia parroquial de Gilena (cortesía de Antonio Manuel Rodríguez). 


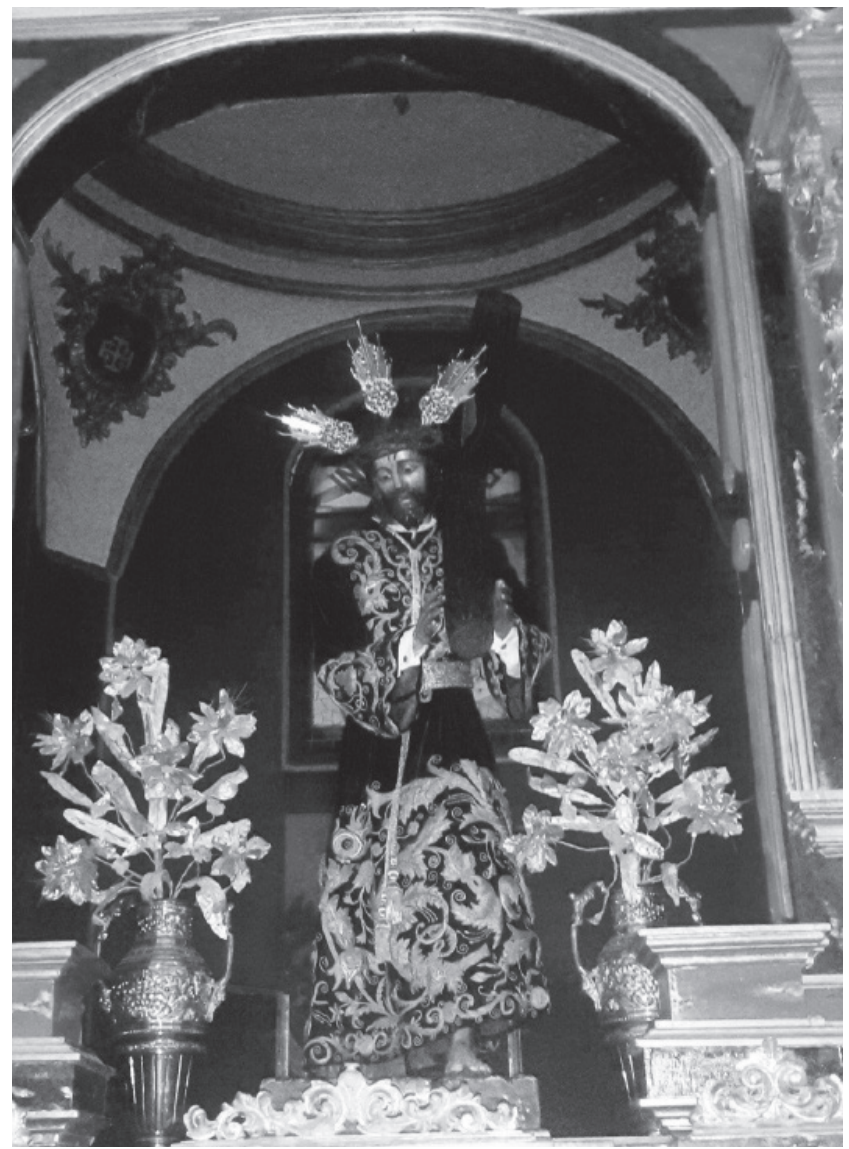

ILUSTRACIÓN 4

Jesús Nazareno. Anónimo. Siglo XviI. Iglesia parroquial de Gilena (cortesía de Antonio Manuel Rodríguez). 